\title{
Proceeding
}

Supplementary Issue: Autumn Conferences of Sports Science. Costa Blanca Sports Science Events, 18-19 December 2020. Alicante, Spain.

\section{A standard for teaching technical competencies of physical education in Egypt according to ISTE (NETS-T) standards}

\author{
AHMED HASSAN 1 , MONA NAJIB², AMR HASSAN ${ }^{3}$ \\ ${ }^{1}$ College of Education, Department of Physical Education, Umm Al-Qura University, Saudi Arabia \\ ${ }^{2}$ Faculty of Physical Education for Girls, Zagazig University, Zagazig, Egypt \\ ${ }^{3}$ Department of Sports Training, Faculty of Sports Education, Mansoura University, Mansoura, Egypt
}

\begin{abstract}
Technology application and internet services are prominent developments in the field of global educational systems. These developments have imposed a change in the role and responsibilities of faculty members and the need to possess technical competencies. Faculty members must apply modern learning theories and organize their learning and evaluation plans based on interactive electronic resources. This study first aimed to suggest a standard of technical teaching competencies for faculty members in physical education under the standards of the International Society for Technology in Education for Teachers (NETS-T). Second, our purpose was to identify the degree to which faculty possess these competencies. The main study involved 812 participants. The exploratory study survey sample consisted of 200 faculty members. The data collection tool consisted of a questionnaire in the form of an opinion poll that included 90 items representing the proposed educational technology competencies within 20 fields representing 5 standards defined by the International Society for Technology in Education for Teachers (ISTE) (NETS-T), 2008. The data collection tool (questionnaire) was evaluated by experts. The exploratory and basic study were carried out using an electronic copy of the questionnaire prepared on Google Forms, and the participation link was sent via emails. Keywords: E-Learning; Sports; Faculty members; Questionnaire.

Cite this article as:

Hassan, A., Najib, M., \& Hassan, A. (2021). A standard for teaching technical competencies of physical education in Egypt according to ISTE (NETS-T) standards. Journal of Human Sport and Exercise, 16(2proc), S221-S238. doi:https://doi.org/10.14198/jhse.2021.16.Proc2.07

Corresponding author. Department of Sports Training, Faculty of Sports Education, Mansoura University, Mansoura, Egypt. https://orcid.org/0000-0002-2053-7644

E-mail: amrahh@mans.edu.eg

Abstract submitted to: Autumn Conferences of Sports Science. Costa Blanca Sports Science Events, 18-19 December 2020. Alicante, Spain.

JOURNAL OF HUMAN SPORT \& EXERCISE ISSN 1988-5202

(c) Faculty of Education. University of Alicante

doi:10.14198/jhse.2021.16.Proc2.07
\end{abstract}




\section{INTRODUCTION}

Technology knowledge is currently an essential component of the competitiveness of countries, universities, and companies. The development of technology allows countries to accelerate innovations as the keys to enhancing productivity and wealth (Escueta, Quan, Nickow, \& Oreopoulos, 2017) (Huggins \& Izushi, 2007).

With the spread of globalization, dependence on higher education institutions increased in order to meet the challenges of this new economic and social environment (Carlsson, 2006).

The law of higher education in Egypt also considers knowledge development by stipulating in its articles the state's commitment to support and promote scientific and technological research activities carried out. Specialized departments in marketing and supporting innovation have been established in Egyptian universities, and their regulations include special provisions for the relations between research and education. Thus, higher education institutions encourage the participation of academic faculty members in educational activities geared towards providing innovative research and technology applications in teaching. For higher education institutions to be able to adapt to the tasks that society imposes on them, they must include mechanisms of generating and transferring knowledge and technology through education, human development, the promotion of cultural and societal development and the provision of opportunities for innovation (De la Orden Hoz, 2007).

It seems that there is agreement in international societies that the global digital agenda highlights the need a change in the educational model of educational institutions to meet the requirements of the new "knowledge society". This change aims to achieve greater flexibility and adoption of learning techniques to modernize and improve teaching and learning processes in formal contexts (Chais, Ganzer, \& Olea, 2017).

The current literatures pay great attention to the increasing spread of technology in higher education (Bajabaa, 2017; Ignatyeva, 2015). Information and communication technology have a great influence on the pedagogy of teaching in universities and vocational training as it includes the collection, organization and use of information in various forms, including sound, images and text, using computers or other telecommunications derivatives (Azma, 2011) (Hamidi, Meshkat, Rezaee, \& Jafari, 2011).

There are many variables that affect the ability of higher education institutions to perform their responsibilities effectively in the field of educational technology applications. The quality of faculty members is undoubtedly one of the most important, as faculty members must in turn possess these competencies, especially at a time when Internet connection is low and accessible to everyone (Angel Alberto Valdés, José Ángel Vera, \& Ernesto Alonso Carlos, 2012). This is most evident when observing the impact of the use of multiple technological media in higher education, which led to changing traditional teaching methods, improving teaching results, and making teaching procedures more active (Chen \& Xia, 2012). However, at the present time, major transformations have already occurred in higher education due to the Covid-19 pandemic faculty members found themselves in a new challenge of continuing education processes, but by relying on more sophisticated technologies. (Rubilar, Alveal, \& Fuentes, 2017). They should "develop and support initiatives that help students gain the skills for both critical thinking, collaboration, effective communication with others, problem-solving, and creativity and innovation."(Govtrack, 2011).

In Egypt, thousands of students are studying physical education sciences in more than 25 universities. The researchers noted the existence of many obstacles that led to the difficulty of continuing the educational process remotely in the field of physical education in Egyptian universities for reasons that may relate to the 
technical capabilities available to faculty members. Therefore, this study aimed to propose a standard for teaching technical competencies for physical education in Egypt according to the ISTE standards (NETS-T) and to assess the extent to which teachers in the Faculties of Physical Education in Egypt possess these competencies.

\section{MATERIALS AND METHODS}

\section{Procedures}

A descriptive and analytical approach was used to identify the educational technology competencies needed by the faculty members in the Faculties of Physical Education under the standards of the International Society for Technology in Education (NETS-T). A field study was employed to determine the degree to which faculty members possess these competencies.

\section{Research community and sample}

The research community represented all faculty members (full-time professor, working professor, assistant professor, teacher doctor) in the Faculties of Physical Education and those on the job in 25 colleges, the survey sample consisted of 200 faculty members outside the basic sample. The electronic link for the study tool was sent to 1650 faculty, and 812 responses were obtained. This study was performed under the Declaration of Helsinki. And as indicated in the instructions for the questionnaire, the respondent's response is considered an agreement to participate in the study.

\section{Data collection tools}

An educational technology competency questionnaire contains five standards with 20 fields and 90 items as:

1. Facilitating and stimulating student learning and creativity (19 items).

2. Design and develop digital age learning experiences and assessments (17 items).

3. Model digital age work and learning (29 items).

4. Promote and model digital citizenship and responsibility (13 items).

5. Engage in professional growth and leadership (12 items).

\section{Steps in designing the questionnaire}

Based on the objectives and questions of the research and by reviewing the standards for measuring educational technology efficiencies in previous studies, the researchers designed a questionnaire concerning educational technology competencies for faculty members in the Faculties of Physical Education under the standards of the International Society for Technology in Education (NETS-T) according to the following steps:

1. The researchers relied on the 2008 version of the International Society for Technology in Teacher Education (NETS-T) in defining the teaching technical competencies of faculty members to provide a complete document including the indicators and performance measures for each indicator.

2. The International Society for Technology in Teacher Education (2008) standards (NETS-T) consists of five sets of standards that include 20 sub-themes.

3. The researchers presented these criteria and their fields to 10 university professors specialized in the field of teaching methods and educational technology to estimate the importance and percentage and determine the relative weights of the fields that belong to these standards (see Table 1).

Table 1 shows the percentage and relative importance as rated by the experts' agreement with the settled standard about the National Educational Technology Standards for Teachers (NETS-T) (2008) that that were used in building the questionnaire $(n=10)$ (Bawane \& Spector, 2009). The researchers accepted the fields agreed upon by all the experts and which got a percentage of $(100 \%)$. 
Table 1. Experts opinions $(n=10)$ of the relative importance of various competencies in the National Educational Technology Standards for Teachers (NETS-T (2008).

\begin{tabular}{|c|c|c|c|c|}
\hline \multirow[b]{2}{*}{ Standard } & \multicolumn{4}{|c|}{ Agreement with the settled standard } \\
\hline & Agree & Disagree & $\begin{array}{c}\text { Chi- } \\
\text { Square }\end{array}$ & $\begin{array}{l}\text { Percentage } \\
\text { Agreement }\end{array}$ \\
\hline $\begin{array}{l}\text { Facilitate and inspire student learning and creativity: } \\
\text { Teachers use their knowledge of subject matter, teaching and learning, and } \\
\text { technology to facilitate experiences that advance student learning, creativity, } \\
\text { and innovation in both face-to-face and virtual environments. }\end{array}$ & 10 & 0 & 10 & $100 \%$ \\
\hline $\begin{array}{l}\text { Design and develop digital age learning experiences and assessments: } \\
\text { Teachers design, develop, and evaluate authentic learning experiences and } \\
\text { assessments incorporating contemporary tools and resources to maximize } \\
\text { content learning in context and to develop the knowledge, skills, and attitudes } \\
\text { identified in the Standards. }\end{array}$ & 10 & 0 & 10 & $100 \%$ \\
\hline $\begin{array}{l}\text { Model digital age work and learning: } \\
\text { Teachers exhibit knowledge, skills, and work processes representative of an } \\
\text { innovative professional in a global and digital society. }\end{array}$ & 10 & 0 & 10 & $100 \%$ \\
\hline $\begin{array}{l}\text { Promote and model digital citizenship and responsibility: } \\
\text { Teachers understand local and global societal issues and responsibilities in } \\
\text { an evolving digital culture and exhibit legal and ethical behaviour in their } \\
\text { professional practices. }\end{array}$ & 10 & 0 & 10 & $100 \%$ \\
\hline $\begin{array}{l}\text { Engage in professional growth and leadership: } \\
\text { Teachers continuously improve their professional practice, model lifelong } \\
\text { learning, and exhibit leadership in their school and professional community } \\
\text { by promoting and demonstrating the effective use of digital tools and } \\
\text { resources. }\end{array}$ & 10 & 0 & 10 & $100 \%$ \\
\hline
\end{tabular}

Table 2. Expert opinions on the proposed items that belong to each field in the questionnaire $(n=10)$.

\begin{tabular}{ccccccccccccccc}
\hline Item & Agree & C-S. & Item & Agree & C-S. & Item & Agree & C-S. & Item & Agree & C-S. & Item & Agree & C-S. \\
\hline $1 / \mathrm{a}$ & & & 20 & 10 & 10.00 & $3 / \mathrm{a}$ & & & 58 & 10 & 10.00 & 78 & 9 & 6.400 \\
1 & 10 & 10.00 & $2 / \mathrm{a}$ & & & 39 & 9 & 6.400 & 59 & 10 & 10.00 & 79 & 9 & 6.400 \\
2 & 9 & 6.400 & 21 & 9 & 6.400 & 40 & 9 & 6.400 & 60 & 10 & 10.00 & $4 / \mathrm{d}$ & & \\
3 & 10 & 10.00 & 22 & 9 & 6.400 & 41 & 9 & 6.400 & 61 & 10 & 10.00 & 80 & 9 & 6.400 \\
4 & 10 & 10.00 & 23 & 9 & 6.400 & 42 & 10 & 10.00 & 62 & 9 & 6.400 & 81 & 9 & 6.400 \\
5 & 10 & 10.00 & $2 / \mathrm{b}$ & & & 43 & 10 & 10.00 & 63 & 10 & 10.00 & 82 & 9 & 6.400 \\
6 & 10 & 10.00 & 24 & 9 & 6.400 & $3 / \mathrm{b}$ & & & 64 & 10 & 10.00 & $5 / \mathrm{a}$ & & \\
7 & 9 & 6.400 & 25 & 10 & 10.00 & 44 & 10 & 10.00 & 65 & 10 & 10.00 & 83 & 9 & 6.400 \\
$1 / \mathrm{b}$ & & & 26 & 10 & 10.00 & 45 & 9 & 6.400 & 66 & 9 & 6.400 & 84 & 10 & 10.00 \\
8 & 9 & 6.400 & 27 & 10 & 10.00 & 46 & 9 & 6.400 & 67 & 9 & 6.400 & 85 & 9 & 6.400 \\
9 & 9 & 6.400 & 28 & 9 & 6.400 & 47 & 10 & 10.00 & 68 & 9 & 6.400 & 86 & 9 & 6.400 \\
10 & 9 & 6.400 & 29 & 10 & 10.00 & 48 & 9 & 6.400 & $4 / \mathrm{a}$ & & & $5 / \mathrm{b}$ & & \\
11 & 10 & 10.00 & $2 / \mathrm{c}$ & & & $3 / \mathrm{c}$ & & & 69 & 9 & 6.400 & 87 & 10 & 10.00 \\
12 & 10 & 10.00 & 30 & 10 & 10.00 & 49 & 10 & 10.00 & 70 & 10 & 10.00 & 88 & 10 & 10.00 \\
$1 / \mathrm{c}$ & & & 31 & 10 & 10.00 & 50 & 10 & 10.00 & 71 & 10 & 10.00 & 89 & 10 & 10.00 \\
13 & 9 & 6.400 & 32 & 10 & 10.00 & 51 & 10 & 10.00 & 72 & 10 & 10.00 & $5 / \mathrm{c}$ & & \\
14 & 9 & 6.400 & $2 / \mathrm{d}$ & & & 52 & 10 & 10.00 & 73 & 10 & 10.00 & 90 & 10 & 10.00 \\
15 & 9 & 6.400 & 33 & 10 & 10.00 & 53 & 10 & 10.00 & $4 / \mathrm{b}$ & & & 91 & 10 & 10.00 \\
16 & 10 & 10.00 & 34 & 10 & 10.00 & $3 / \mathrm{d}$ & & & 74 & 10 & 10.00 & $5 / \mathrm{d}$ & & \\
$1 / \mathrm{d}$ & & & 35 & 10 & 10.00 & 54 & 9 & 6.400 & 75 & 10 & 10.00 & 92 & 10 & 10.00 \\
17 & 10 & 10.00 & 36 & 10 & 10.00 & 55 & 10 & 10.00 & 76 & 10 & 10.00 & 93 & 10 & 10.00 \\
18 & 10 & 10.00 & 37 & 10 & 10.00 & 56 & 10 & 10.00 & $4 / \mathrm{c}$ & & & 94 & 10 & 10.00 \\
19 & 9 & 6.400 & 38 & 10 & 10.00 & 57 & 10 & 10.00 & 77 & 10 & 10.00 & 95 & 10 & 10.00 \\
\hline
\end{tabular}

Note: Item = Item Number; C-S = Chi-Square. The tabular Chi-Square value at the level of significance $.05=3.840$. 


\section{Formulation of questionnaire items}

In line with the expert opinions about the standards and fields of each standard, the researchers prepared the appropriate items for each field. Each item was formulated in a clear and specific manner. This was done through a reference survey and review of previous studies and references to formulate educational technology competencies for each field as well as the opinions of experts. The researchers took care when formulating the items to be clear and understandable, avoiding difficult words or suggesting the type of response and avoiding duplicating the phrase. The items were designed to measure every aspect of the field to which they belong. The questionnaire in its initial form reached 95 items. The questionnaire was presented to experts. The aim was to evaluate the appropriateness of the items for each field (see Table 2).

It is evident from Table 2 that the values of Chi-Square for all expressions were statistically significant, as the calculated Chi-Square value was greater than its table value.

\section{Questionnaire correction method}

In this stage the questionnaire included 95 items, and each statement of the questionnaire was answered using a Likert five-response scale which were: (I own it very much - I own it to a great extent - I own it with an average degree - I own it with a weak degree - I do not own it), so that the scores were given (5-4-3-2-1), and accordingly, the maximum score for the questionnaire was 450 and the minimum score was 95 . A high score on the questionnaire indicated a high degree of possession of educational technology competencies for respondents.

\section{Instructions for the questionnaire}

The instructions for the questionnaire are one of the important factors for its application. Instructions entail clarity of the purpose of the survey and how it is performed. The researchers took care to develop guidelines that clarified the target group in the research. This included: The reason for their selection for participation and their rights to maintain the confidentiality of their answers, the aim of the questionnaire, and the ability to communicate with researchers for any inquiries, in addition to recording the correct data in the space designated for it. This was done easily and soundly while avoiding prolonged and unclear communications.

\section{Research executive steps}

The pre-study

The exploratory study was carried out in the period from $5 / 23$ to $5 / 31 / 2020$, on a sample of 200 faculty members. The purpose of conducting the exploratory study was to verify the validity and reliability of the questionnaire.

Validity of internal consistency of the terms and dimensions of the standard

The proposed questionnaire was applied to an exploratory sample of 200 faculty members in order to evaluate scientific parameters and ensure the validity of the proposed questionnaire for application. The validity of the internal consistency was verified by finding the correlation coefficient between the score of each statement by itself and the total score of the field to which it belonged, the score of each field, and the total score of the questionnaire on the pilot study sample, as shown in Tables No. 5 and 6 (see Table 3).

It is evident from Table 3 that there was a statistically significant correlation between the degree of each statement and the field to which it belongs, except for the expressions №. 19, 38, 68, 80, 95 because they were not statistically significant, and all the remaining correlation coefficients were significant (.05) This is an indicator of the validity of the internal structure of the questionnaire items. Accordingly, the questionnaire was prepared in the final electronically for the application (90 items) (see Table 4). 
Table 3. The Spearman's correlation coefficient between the score for the items and the total score of each field of the questionnaire to which it belongs $(n=200)$.

\begin{tabular}{cccccccccc}
\hline Item number & $\mathbf{r}$ & Item number & $\mathbf{r}$ & Item number & $\mathbf{r}$ & Item number & $\mathbf{r}$ & Item number & $\mathbf{r}$ \\
\hline $1 / \mathrm{a}$ & & 20 & 0.78 & $3 / \mathrm{a}$ & & 58 & 0.56 & 78 & 0.66 \\
1 & 0.85 & $2 / \mathrm{a}$ & & 39 & 0.56 & 59 & 0.36 & 79 & 0.64 \\
2 & 0.74 & 21 & 0.74 & 40 & 0.86 & 60 & 0.45 & $4 / \mathrm{d}$ & \\
3 & 0.85 & 22 & 0.77 & 41 & 0.67 & 61 & 0.67 & 80 & -0.05 \\
4 & 0.89 & 23 & 0.70 & 42 & 0.45 & 62 & 0.45 & 81 & 0.95 \\
5 & 0.85 & $2 / \mathrm{b}$ & & 43 & 0.26 & 63 & 0.36 & 82 & 0.89 \\
6 & 0.75 & 24 & 0.75 & $3 / \mathrm{b}$ & & 64 & 0.46 & $5 / \mathrm{a}$ & \\
7 & 0.74 & 25 & 0.74 & 44 & 0.67 & 65 & 0.67 & 83 & 0.36 \\
$1 / \mathrm{b}$ & & 26 & 0.70 & 45 & 0.86 & 66 & 0.37 & 84 & 0.36 \\
8 & 0.774 & 27 & 0.95 & 46 & 0.75 & 67 & 0.35 & 85 & 0.55 \\
9 & 0.83 & 28 & 0.87 & 47 & 0.70 & 68 & -0.66 & 86 & 0.37 \\
10 & 0.80 & 29 & 0.77 & 48 & 0.56 & $4 / \mathrm{a}$ & & $5 / \mathrm{b}$ & \\
11 & 0.63 & $2 / \mathrm{c}$ & & $3 / \mathrm{c}$ & & 69 & 0.63 & 87 & 0.70 \\
12 & 0.46 & 30 & 0.86 & 49 & 0.66 & 70 & 0.37 & 88 & 0.66 \\
$1 / \mathrm{c}$ & & 31 & 0.66 & 50 & 0.66 & 71 & 0.42 & 89 & 0.64 \\
13 & 0.85 & 32 & 0.46 & 51 & 0.75 & 72 & 0.66 & $5 / \mathrm{c}$ & \\
14 & 0.75 & $2 / \mathrm{d}$ & & 52 & 0.67 & 73 & 0.65 & 90 & 0.67 \\
15 & 0.69 & 33 & 0.56 & 53 & 0.49 & $4 / \mathrm{b}$ & & 91 & 0.63 \\
16 & 0.67 & 34 & 0.49 & $3 / \mathrm{d}$ & & 74 & 0.64 & $5 / \mathrm{d}$ & \\
$1 / \mathrm{d}$ & & 35 & 0.67 & 54 & 0.34 & 75 & 0.46 & 92 & 0.66 \\
17 & 0.85 & 36 & 0.47 & 55 & 0.54 & 76 & 0.67 & 93 & 0.48 \\
18 & 0.77 & 37 & 0.55 & 56 & 0.56 & $4 / \mathrm{c}$ & & 94 & 0.49 \\
19 & 0.02 & 38 & 0.02 & 57 & 0.66 & 77 & 0.45 & 95 & 0.10 \\
\hline
\end{tabular}

Table 4. The Spearman's correlation coefficients between the sum of the items of each field and the total sum of the questionnaire $(n=200)$.

\begin{tabular}{|c|c|c|c|}
\hline No & Standards/fields & Items & $r$ \\
\hline $1 / \mathrm{a}$ & Promote, support, and model creative and innovative thinking and inventiveness. & 7 & $0.95^{*}$ \\
\hline $1 / b$ & $\begin{array}{l}\text { Engage students in exploring real-world issues and solving authentic problems using digital tools and } \\
\text { resources. }\end{array}$ & 5 & $0.67^{*}$ \\
\hline $1 / c$ & $\begin{array}{l}\text { Promote student reflection using collaborative tools to reveal and clarify students' conceptual } \\
\text { understanding and thinking, planning, and creative processes. }\end{array}$ & 4 & $0.36^{*}$ \\
\hline $1 / \mathrm{d}$ & $\begin{array}{l}\text { Model collaborative knowledge construction by engaging in learning with students, colleagues, and } \\
\text { others in face-to-face and virtual environments. }\end{array}$ & 3 & $0.67^{*}$ \\
\hline 2/a & $\begin{array}{l}\text { Design or adapt relevant learning experiences that incorporate digital tools and resources to promote } \\
\text { student learning and creativity. }\end{array}$ & 3 & $0.46^{*}$ \\
\hline $2 / b$ & $\begin{array}{l}\text { Develop technology-enriched learning environments that enable all students to pursue their individual } \\
\text { curiosities and become active participants in setting their own educational goals, managing their own } \\
\text { learning, and assessing their own progress. }\end{array}$ & 6 & $0.85^{*}$ \\
\hline $2 / c$ & $\begin{array}{l}\text { Customize and personalize learning activities to address students' diverse learning styles, working } \\
\text { strategies, and abilities using digital tools and resources. }\end{array}$ & 3 & $0.64^{*}$ \\
\hline $2 / d$ & $\begin{array}{l}\text { Provide students with multiple and varied formative and summative assessments aligned with content } \\
\text { and technology standards, and use resulting data to inform learning and teaching. }\end{array}$ & 5 & $0.89^{*}$ \\
\hline 3/a & $\begin{array}{l}\text { Demonstrate fluency in technology systems and the transfer of current knowledge to new technologies } \\
\text { and situations. }\end{array}$ & 5 & $0.745^{*}$ \\
\hline $3 / b$ & $\begin{array}{l}\text { Collaborate with students, peers, parents, and community members using digital tools and resources } \\
\text { to support student success and innovation. }\end{array}$ & 5 & $0.66^{*}$ \\
\hline $3 / c$ & $\begin{array}{l}\text { Communicate relevant information and ideas effectively to students, parents, and peers using a variety } \\
\text { of digital-age media and formats. }\end{array}$ & 5 & $0.47^{*}$ \\
\hline $3 / d$ & $\begin{array}{l}\text { Model and facilitate effective use of current and emerging digital tools to locate, analyse, evaluate, and } \\
\text { use information resources to support research and learning. }\end{array}$ & 14 & $0.56^{*}$ \\
\hline
\end{tabular}




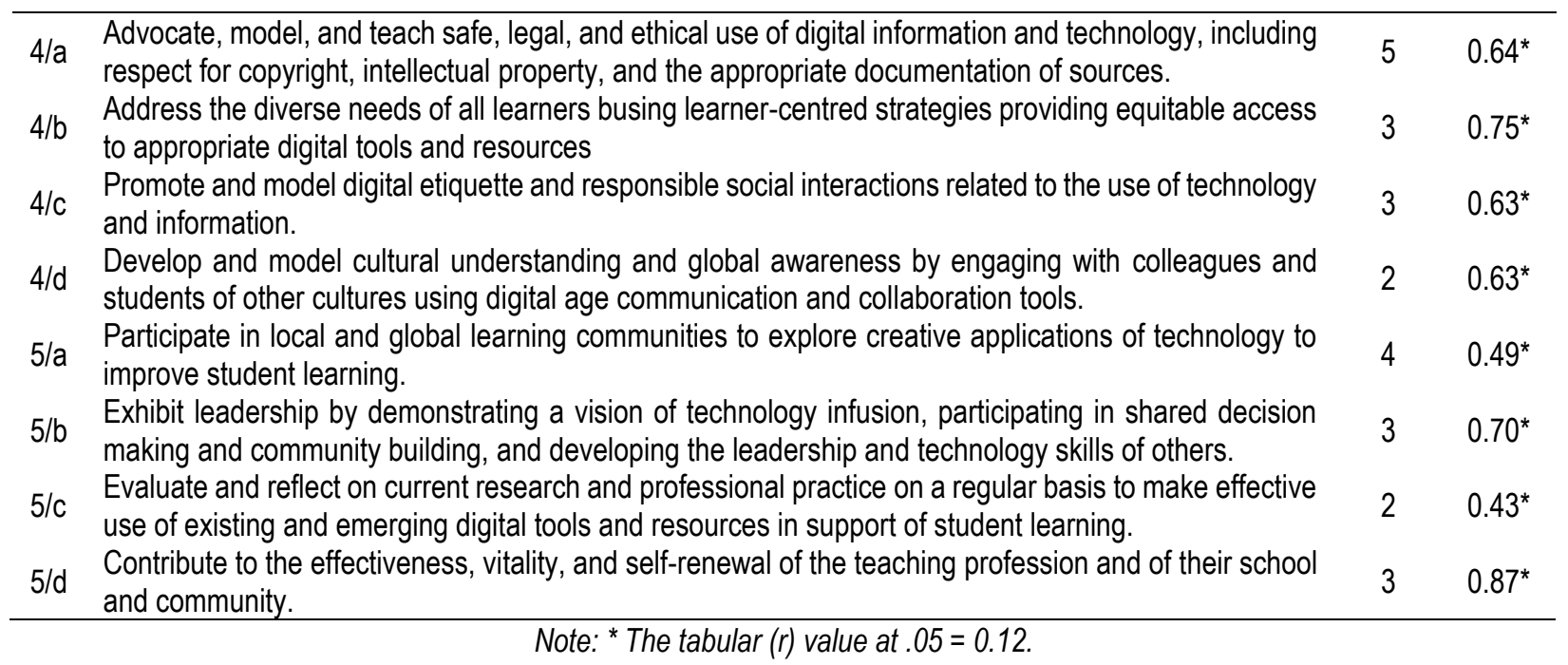

It is evident from Table 4 that there was a significant correlational relationship between the sum of the expressions of each field and the total sum of the questionnaire which indicates internal consistency between the fields and the total sum for the questionnaire.

The split-half reliability coefficient of the proposed questionnaire of educational technology efficiencies was found on the exploratory sample of 200 faculty members, which included 20 fields and 90 items, as can be seen in Table 1.

It is clear from Table 5 that the correlation coefficients ranged between 0.36 and 0.96 , which indicates that the questionnaire had a high coefficient of stability. The questionnaire final version included 90 items distributed on 20 field within 5 criteria and are intended for application to the research community.

The basic study

The basic study was carried out in the period from $1 / 6$ to 6/20/2020, where the final version of the questionnaire was prepared using Google Forms and administered by sending the electronic link via the phone via WhatsApp and through the Facebook Messenger application. The link was sent to 1650 faculty members, and 812 responses were obtained.

\section{RESULTS}

Table 6 shows the percentage of availability of technical competency standards for teaching for the five standards and sub-axes, which were moderate to less than average in general. More details for items are presented in Appendix Table 7.

Figure 1 shows, there is a discrepancy in the percentage of availability of technical competence for teaching between the fields in each standard, especially the second, third and fourth criteria, which indicates a deficiency in technological qualifications for university staff members in the field of physical education. 
Table 6. Mean, standard deviation and, percentage of availability of the teaching technical competency standards.

\begin{tabular}{|c|c|c|c|c|c|}
\hline Standard / Field & Mean & SD & Skewness & Kurtosis & $\%$ \\
\hline Items & Statistic & Statistic & Statistic & Statistic & 70 \\
\hline $\begin{array}{l}\text { 1. Facilitate and inspire student learning and creativity } \\
\text { Teachers use their knowledge of subject matter, teaching and } \\
\text { learning, and technology to facilitate experiences that advance } \\
\text { student learning, creativity, and innovation in both face-to-face } \\
\text { and virtual environments. }\end{array}$ & 45.9 & 14.1 & 1.6 & 1.3 & $48.3 \%$ \\
\hline $\begin{array}{l}\text { a. Promote, support, and model creative and innovative thinking and } \\
\text { inventiveness }\end{array}$ & 15.9 & 6.3 & 1.5 & 1.1 & $45.4 \%$ \\
\hline $\begin{array}{l}\text { b. Engage students in exploring real-world issues and solving } \\
\text { authentic problems using digital tools and resources }\end{array}$ & 13.5 & 4.1 & 1.2 & 0.9 & $53.8 \%$ \\
\hline $\begin{array}{l}\text { c. Promote student reflection using collaborative tools to reveal and } \\
\text { clarify students' conceptual understanding and thinking, planning, } \\
\text { and creative processes. }\end{array}$ & 9.9 & 2.9 & 1.8 & 2.5 & $49.4 \%$ \\
\hline $\begin{array}{l}\text { d. Model collaborative knowledge construction by engaging in } \\
\text { learning with students, colleagues, and others in face-to-face and } \\
\text { virtual environments. }\end{array}$ & 6.7 & 1.6 & 1.8 & 2.7 & $44.5 \%$ \\
\hline $\begin{array}{l}\text { 2. Design and develop digital age learning experiences and } \\
\text { assessments Teachers design, develop, and evaluate } \\
\text { authentic learning experiences and assessments } \\
\text { incorporating contemporary tools and resources to maximize } \\
\text { content learning in context and to develop the knowledge, } \\
\text { skills, and attitudes identified in the Standards. }\end{array}$ & 34.6 & 9.9 & 1.5 & 1.7 & $46.1 \%$ \\
\hline $\begin{array}{l}\text { a. Design or adapt relevant learning experiences that incorporate } \\
\text { digital tools and resources to promote student learning and creativity }\end{array}$ & 7.5 & 2.0 & 0.0 & -0.9 & $49.7 \%$ \\
\hline $\begin{array}{l}\text { b. Develop technology-enriched learning environments that enable } \\
\text { all students to pursue their individual curiosities and become active } \\
\text { participants in setting their own educational goals, managing their } \\
\text { own learning, and assessing their own progress }\end{array}$ & 13.8 & 5.4 & 1.7 & 1.6 & $45.9 \%$ \\
\hline $\begin{array}{l}\text { c. Customize and personalize learning activities to address } \\
\text { students' diverse learning styles, working strategies, and abilities } \\
\text { using digital tools and resources }\end{array}$ & 4.6 & 3.2 & 1.8 & 2.0 & $30.8 \%$ \\
\hline $\begin{array}{l}\text { d. Provide students with multiple and varied formative and } \\
\text { summative assessments aligned with content and technology } \\
\text { standards, and use resulting data to inform learning and teaching }\end{array}$ & 13.3 & 3.5 & 1.6 & 2.5 & $53.4 \%$ \\
\hline $\begin{array}{l}\text { 3. Model digital age work and learning Teachers exhibit } \\
\text { knowledge, skills, and work processes representative of an } \\
\text { innovative professional in a global and digital society. }\end{array}$ & 82.0 & 13.5 & 1.6 & 3.3 & $56.6 \%$ \\
\hline $\begin{array}{l}\text { a. Demonstrate fluency in technology systems and the transfer of } \\
\text { current knowledge to new technologies and situations }\end{array}$ & 7.4 & 2.1 & 4.2 & 44.3 & $29.7 \%$ \\
\hline $\begin{array}{l}\text { b. Collaborate with students, peers, parents, and community } \\
\text { members using digital tools and resources to support student } \\
\text { success and innovation }\end{array}$ & 10.8 & 3.7 & 2.1 & 4.1 & $43.1 \%$ \\
\hline $\begin{array}{l}\text { c. Communicate relevant information and ideas effectively to } \\
\text { students, parents, and peers using a variety of digital-age media } \\
\text { and formats. }\end{array}$ & 15.6 & 2.6 & 1.2 & 3.2 & $62.3 \%$ \\
\hline $\begin{array}{l}\text { d. Model and facilitate effective use of current and emerging digital } \\
\text { tools to locate, analyse, evaluate, and use information resources to } \\
\text { support research and learning. }\end{array}$ & 48.2 & 7.2 & 0.6 & 4.2 & $68.9 \%$ \\
\hline $\begin{array}{l}\text { 4. Promote and model digital citizenship and responsibility } \\
\text { Teachers understand local and global societal issues and } \\
\text { responsibilities in an evolving digital culture and exhibit legal } \\
\text { and ethical behaviour in their professional practices. }\end{array}$ & 33.6 & 8.5 & 1.7 & 2.3 & $51.7 \%$ \\
\hline
\end{tabular}




\begin{tabular}{|c|c|c|c|c|c|}
\hline $\begin{array}{l}\text { a. Advocate, model, and teach safe, legal, and ethical use of digital } \\
\text { information and technology, including respect for copyright, } \\
\text { intellectual property, and the appropriate documentation of sources }\end{array}$ & 13.0 & 3.9 & 1.5 & 1.9 & $51.8 \%$ \\
\hline $\begin{array}{l}\text { b. Address the diverse needs of all learners busing learner-centred } \\
\text { strategies providing equitable access to appropriate digital tools and } \\
\text { resources }\end{array}$ & 8.9 & 2.1 & 1.1 & 2.2 & $59.3 \%$ \\
\hline $\begin{array}{l}\text { c. Promote and model digital etiquette and responsible social } \\
\text { interactions related to the use of technology and information }\end{array}$ & 8.2 & 2.5 & 1.3 & 1.3 & $54.4 \%$ \\
\hline $\begin{array}{l}\text { d. Develop and model cultural understanding and global awareness } \\
\text { by engaging with colleagues and students of other cultures using } \\
\text { digital age communication and collaboration tools }\end{array}$ & 3.6 & 0.8 & 1.0 & 0.9 & $36.2 \%$ \\
\hline $\begin{array}{l}\text { 5. Engage in professional growth and leadership Teachers } \\
\text { continuously improve their professional practice, model } \\
\text { lifelong learning, and exhibit leadership in their school and } \\
\text { professional community by promoting and demonstrating the } \\
\text { effective use of digital tools and resources. }\end{array}$ & 27.1 & 9.7 & 1.9 & 2.6 & $45.2 \%$ \\
\hline $\begin{array}{l}\text { a. Participate in local and global learning communities to explore } \\
\text { creative applications of technology to improve student learning. }\end{array}$ & 8.3 & 1.9 & 1.4 & 3.9 & $41.3 \%$ \\
\hline $\begin{array}{l}\text { b. Exhibit leadership by demonstrating a vision of technology } \\
\text { infusion, participating in shared decision making and community } \\
\text { building, and developing the leadership and technology skills of } \\
\text { others. }\end{array}$ & 7.8 & 3.9 & 1.8 & 2.0 & $52.3 \%$ \\
\hline $\begin{array}{l}\text { c. Evaluate and reflect on current research and professional practice } \\
\text { on a regular basis to make effective use of existing and emerging } \\
\text { digital tools and resources in support of student learning. }\end{array}$ & 4.7 & 1.6 & 2.0 & 3.1 & $47 \%$ \\
\hline $\begin{array}{l}\text { d. Contribute to the effectiveness, vitality, and self-renewal of the } \\
\text { teaching profession and of their school and community }\end{array}$ & 6.3 & 2.8 & 1.8 & 1.9 & $42.1 \%$ \\
\hline
\end{tabular}

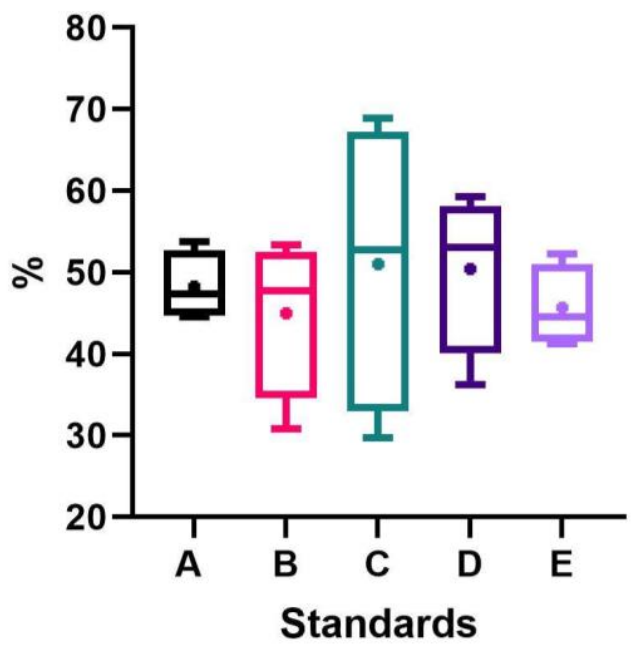

Figure 1. The variation between averages and percentages of the availability of teaching technical competency standards.

\section{DISCUSSION}

\section{Standard (1)}

The first standard that deals with employing teachers for their knowledge of the learning subject in helping students to create and innovate in the real and virtual environment, the percentage of availability of technical competence to teach by it was $48.30 \%$. 
The weakness of these competencies is justified by the fact that the real environment for teaching in the Faculties of Physical Education in Egypt does not depend on learning management systems, through which a creative environment can be created for communication and discussions through educational forums and virtual classes. Individual and group learning activities, research, participation, exchange of ideas, communication with experts, and team management cannot be implemented.

There is no employment of digital educational elements, educational applications in teaching, the use of internet in educational research, delivery of educational content and receipt of activities and assignments online. In addition, there is no systematic plan in the colleges to commit to converting academic courses to the electronic system according to the technical and educational specifications and reassess them before putting them for use. The development is left to the effort and vision of the faculty member, and therefore no actual practices were exposed to how to design and apply these technical techniques in teaching.

Even if these electronic courses are available, they are not subject to accurate evaluation by specialists in terms of scientific, technical, and technological for digital content and according to the objectives of those courses. The are no preformed digital educational units in form ready for use so, there is still almost total dependence on traditional education.

\section{Standard (2)}

There was a slight improvement in the result of possessing the technical competencies to teach in the second axis. This may be mainly because these competencies include electronic test design programs. These tests can be used and training on how to design them through available online training programs and university courses.

However, the lack of a complete mechanism for implementing the electronic testing system for reasons related to the university system, equipment and internet connection has led to a lack of interest in developing it. In addition to the lack of a scientific vision on the mechanism of employing electronic tests in the practical evaluation of the specializations in physical education and sports.

But the low percentage in general is because the educational system in most Egyptian universities in the field of physical education is based on a semester system that does not allow teachers to plan various educational strategies and learning methods to students' experiences. Also, the cooperative educational activities are not applied between students for the research and development of electronic educational content.

In addition, failure to apply various educational strategies due to lack of reliance on the virtual educational environment. Finally, the limited application of technology on the med-Term and finals assessments.

\section{Standard (3)}

The percentage in the third standard was higher than the average with a large variation between the lowest and largest percentage in the field representing the standard. This is due to what this standard address in terms of the competencies of faculty members dealing with hardware and software problems that occur during use. As some universities have specialized departments in technical support as well as assistance in producing educational materials for those who are interested in faculty members.

While some percentages decrease due to the standard addressing technical competencies related to communicating with learners from other countries or participating in the production of international works, exchange of information and solving common problems between international universities, and such 
requirements do not apply to Egyptian educational programs in the field of sports education. There are external factors that include outsider influences that faculty members have no control over that allow them to successfully integrate technology. For example, evaluate digital tools and resources (Ertmer, 1999; Ertmer, Ottenbreit-Leftwich, \& York, 2007; Salentiny \& Van Eck, 2012; Tondeur et al., 2012; Yuksel, Soner, \& Zahide, 2009).

\section{Standard (4)}

The percentage in the fourth standard was higher than the average with a variation between the lowest and largest percentage in the fields representing the standard.

In some few Egyptian universities, there have been attempts to implement an e-learning system during the lockdown resulting from the Covid-19 pandemic, which has led to focusing attention on the use of widely diverse technology in the educational process. This contributed to documenting digital information sources and official websites in the field of specialization with the participation of students and increasing awareness of the culture of intellectual property rights for digital content among students and faculty members.

It also led to an increase in the use of licensed digital protection systems for the computer operating system and the smart phone and an increase in communication and communication processes to identify obstacles to the use of educational technologies and provide solutions to them.

\section{Standard (5)}

The percentage in the fourth criterion was less than the average with little variation between the lowest and largest percentage in the axes representing the standard.

This is due to the lack of a systematic plan to take advantage of modern technology in the sports field in particular. Also, there are no proposed solutions to solve problems related to distance learning and to study how to prepare and present educational courses for the sports field in a digital form in a technical and technical manner characterized by high quality. In addition to that, if some of these digital courses are available, they are not subject to scientific, technical, and educational review by educational technology professionals, so that all aspects are available to produce them well.

The researchers also attribute that result to the lack of educational software industry for the sports field, which needs support from e-learning centres in a professional and specialized manner.

There is no digital content for the major as part of international student attraction projects. Therefore, these factors affected the reduction of the technological competencies of the faculty members, as they were not exposed to the practice of those competencies or training on them previously.

Finally, these results showed a minimum awareness ( $50 \%)$ of Egyptian faculty members in the field of physical education in using technology based on ISTE NETS-T. However, it is considered a weak awareness compared to Lewis (2013) results that showed $83 \%$ of faculty interviewed that they were familiar with the ISTE NETS-T standards (Lewis, 2013). The recommendations are consistent with Bajabaa (2017) where it should the qualification and assistance of faculty members in Physical Education to model the effective use of technology in a variety and lesson plans tasks and projects. 
The leaders of the College of Sports Education are advised to have a clear common technical vision and to provide the resources and support necessary for the successful integration of educational technology in the academic sports field.

\section{CONCLUSIONS}

The findings from the study present a standard for teaching technical competencies of the faculty members of the Faculties of Physical Education in Egypt according to International Society for Technology in Education (ISTE) National Educational Technology Standards for Teachers (NETS-T).

The results are valuable and beneficial for guiding educational regulators in providing an appropriate evaluation of the current skills and situation of university lecturers. Access to these outcomes will contribute to future research on technological competencies in education.

\section{CONFLICT OF INTERESTS}

The authors declared no conflict of interests concerning this manuscript.

\section{ACKNOWLEDGMENTS}

To all authors who have supported the paper's procedures.

\section{REFERENCES}

Angel Alberto Valdés, C., José Ángel Vera, N., \& Ernesto Alonso Carlos, M. (2012). Measurement of scientific competences in professors of technological higher education. Avaliação: Revista da Avaliação da Educação Superior (Campinas), 17(1), 237-254.

Azma, F. (2011). The Quality Indicators of Information Technology in Higher Education. Procedia - Social and Behavioral Sciences, 30, 2535-2537. https://doi.org/10.1016/j.sbspro.2011.10.494

Bajabaa, A. S. (2017). Influential factors and faculty members' practices in technology integration using ISTE standards for teacher preparation at Taibah University- Saudi Arabia. (Doctor of Philosophy Doctor ), Kansas State University, Manhattan, Kan. Retrieved from http://hdl.handle.net/2097/35805

Bawane, J., \& Spector, J. M. (2009). Prioritization of Online Instructor Roles: Implications for Competency-Based Teacher Education Programs. Distance Education, 30(3), 383-397. https://doi.org/10.1080/01587910903236536

Carlsson, B. (2006). Internationalization of innovation systems: a survey of the literature. Research policy, 35(1), 56-67. https://doi.org/10.1016/j.respol.2005.08.003

Chais, C., Ganzer, P. P., \& Olea, P. M. (2017). Technology transfer between universities and companies: two cases of Brazilian universities. RAl Revista de Administração e Inovação RAl Revista de Administração e Inovação. https://doi.org/10.1108/INMR-02-2018-002

Chen, S., \& Xia, Y. (2012). Research on Application of Multimedia Technology in College Physical Education. Procedia Engineering, 29, 4213-4217. https://doi.org/10.1016/j.proeng.2012.01.645

De la Orden Hoz, A., Asensio Muñoz, I., Biencinto López, C., González Barberá, C., \& Mafokozi Ndabishibije, J. (2007). Levels and Profiles of Functionality as Dimensions of University Quality: An Empirical Study of Universidad Complutense. education policy analysis archives, 15, 12. https://doi.org/10.14507/epaa.v15n12.2007 
Ertmer, P. A. (1999). Addressing First- and Second-Order Barriers to Change: Strategies for Technology Integration. edutechresedeve Educational Technology Research and Development, 47(4), 47-61. https://doi.org/10.1007/BF02299597

Ertmer, P. A., Ottenbreit-Leftwich, A., \& York, C. S. (2007). Exemplary Technology-Using Teachers: Perceptions of Factors Influencing Success. Journal of Computing in Teacher Education, 23(2), 5561.

Escueta, M., Quan, V., Nickow, A. J., \& Oreopoulos, P. (2017). Education Technology : an EvidenceBased Review. In M. N. B. o. E. Research (Ed.), (pp. 23744). https://doi.org/10.3386/w23744

Govtrack. (2011). 21st century skills readiness act. Retrieved from https://www.govtrack.us/congress/bills/112/s1175/text

Hamidi, F., Meshkat, M., Rezaee, M., \& Jafari, M. (2011). Information technology in education. Procedia Computer Science, 3, 369-373. https://doi.org/10.1016/..procs.2010.12.062

Huggins, R., \& Izushi, H. (2007). Competing for knowledge : creating, connecting, and growing. London; New York: Routledge. https://doi.org/10.4324/9780203940594

Ignatyeva, I. (2015). The Trend of Technologisation of Modern Education (the Use of Humanitarian Technologies). Procedia - Social and Behavioral Sciences, 214, 606-613. https://doi.org/10.1016/j.sbspro.2015.11.766

Lewis, C. L. (2013). Preservice Teachers' Ability to Identify Technology Standards: Does Curriculum Matter? : ProQuest LLC. 789 East Eisenhower Parkway, P.O. Box 1346, Ann Arbor, Ml 48106. Tel: 800-521-0600; Web site: http://www.proquest.com/en-US/products/dissertations/individuals.shtml

Rubilar, P. S., Alveal, F. R., \& Fuentes, A. C. M. (2017). Evaluación de la alfabetización digital y pedagógica en TIC, a partir de las opiniones de estudiantes en Formación Inicial Docente \%J Educação e Pesquisa. 43, 127-143. https://doi.org/10.1590/s1517-9702201701154907

Salentiny, Adrienne M., "Analysis Of Preservice Teacher And Instructor Technology Uses And Beliefs" (2012). Theses and Dissertations. 1268. Retrieved from: https://commons.und.edu/theses/1268

Tondeur, J., van Braak, J., Sang, G., Voogt, J., Fisser, P., \& Ottenbreit-Leftwich, A. (2012). Preparing Pre-Service Teachers to Integrate Technology in Education: A Synthesis of Qualitative Evidence. Computers \& Education, 59(1), 134-144. https://doi.org/10.1016/j.compedu.2011.10.009

Yuksel, G., Soner, Y., \& Zahide, Y. (2009). Main Barriers and Possible Enablers of ICTs Integration into Pre-service Teacher Education Programs. jeductechsoci Journal of Educational Technology \& Society, 12(1), 193-204. 


\section{APPENDIX}

Table 7. Descriptive Statistics of the questionnaire responses (Higher score $=$ greater confidence 5-1 scale).

\begin{tabular}{|c|c|c|c|c|c|c|}
\hline $\begin{array}{l}\text { Standard / Field/ Efficiency } \\
\text { Items }\end{array}$ & $\begin{array}{c}\text { Mean } \\
\text { Statistic }\end{array}$ & $\begin{array}{c}\text { SD } \\
\text { Statistic }\end{array}$ & $\begin{array}{l}\text { Skewness } \\
\text { Statistic }\end{array}$ & SE & $\begin{array}{l}\text { Kurtosis } \\
\text { Statistic }\end{array}$ & SE \\
\hline \multicolumn{7}{|c|}{$\begin{array}{l}\text { 1. Facilitate and inspire student learning and creativity Teachers use their knowledge of subject matter, teaching and learning, and technology } \\
\text { to facilitate experiences that advance student learning, creativity, and innovation in both face-to-face and virtual environments. }\end{array}$} \\
\hline \multicolumn{7}{|c|}{ a. Promote, support, and model creative and innovative thinking and inventiveness } \\
\hline $\begin{array}{l}\text { 1. Creates a creative environment for } \\
\text { communication and discussions via educational } \\
\text { forums and virtual classes. }\end{array}$ & 1.71 & 1.24 & 1.53 & 0.08 & 0.93 & 0.17 \\
\hline $\begin{array}{l}\text { 2. Design individual and group learning activities } \\
\text { through distance learning platforms. }\end{array}$ & 1.64 & 1.23 & 1.65 & 0.08 & 1.22 & 0.17 \\
\hline $\begin{array}{l}\text { 3. Prepares and manages work teams among } \\
\text { students via remote communication applications. }\end{array}$ & 1.70 & 1.32 & 1.57 & 0.08 & 0.85 & 0.17 \\
\hline $\begin{array}{l}\text { 4. Formulates activities that encourage the } \\
\text { employment of digital components to provide } \\
\text { knowledge and skill assignments. }\end{array}$ & 2.69 & 0.83 & 0.87 & 0.08 & 0.65 & 0.17 \\
\hline $\begin{array}{l}\text { 5. Evaluates the suitability of the digital content on } \\
\text { the information network according to the course } \\
\text { objectives. }\end{array}$ & 2.70 & 0.85 & 0.93 & 0.08 & 0.58 & 0.17 \\
\hline $\begin{array}{l}\text { 6. Employ modern and appropriate electronic } \\
\text { educational applications in teaching. }\end{array}$ & 2.74 & 0.93 & 1.05 & 0.08 & 0.25 & 0.17 \\
\hline $\begin{array}{l}\text { 7. Teaching is planned using remote digital content } \\
\text { management applications (Blackboard / Moodle). }\end{array}$ & 2.69 & 0.85 & 0.74 & 0.08 & 0.87 & 0.17 \\
\hline \multicolumn{7}{|c|}{ b. Engage students in exploring real-world issues and solving authentic problems using digital tools and resources } \\
\hline $\begin{array}{l}\text { 8. Participates in designing electronic tutorials for the } \\
\text { course using one of the presentation programs. }\end{array}$ & 2.70 & 1.08 & 0.78 & 0.08 & -0.01 & 0.17 \\
\hline $\begin{array}{l}\text { 9. Implement educational activities related to the } \\
\text { theoretical and practical content through appropriate } \\
\text { e-learning methods and methods. }\end{array}$ & 2.70 & 0.99 & 0.83 & 0.08 & 0.17 & 0.17 \\
\hline $\begin{array}{l}\text { 10. Prepare the educational units in digital form a } \\
\text { methodology ready for learning when exposed to } \\
\text { any crises that hinder the continuation of the } \\
\text { educational process. }\end{array}$ & 2.69 & 1.04 & 0.33 & 0.08 & 0.01 & 0.17 \\
\hline $\begin{array}{l}\text { 11. Design self-learning distance activities that allow } \\
\text { students to research and participate in assessing the } \\
\text { digital content of the course. }\end{array}$ & 1.70 & 1.18 & 1.61 & 0.08 & 1.39 & 0.17 \\
\hline 12. Design a digital question bank for the course. & 3.64 & 0.78 & -0.63 & 0.08 & 1.20 & 0.17 \\
\hline
\end{tabular}

c. Promote student reflection using collaborative tools to reveal and clarify students' conceptual understanding and thinking, planning, and creative processes.

13. Design educational activities that allow students

1.53

1.05

1.81

0.08

2.15

0.17

to communicate remotely with experts, benefit from the advice and offer it technically.

14. Design virtual collaborative learning activities to display and discuss educational topics across forums and virtual classes.

15. Design educational activities that allow students to participate in the design and presentation of digital distance learning materials / in a classroom.

16. Using educational online services to search and

1.53

1.05

1.81

0.08

2.15

0.17 communicate, deliver educational content and

1.59

1.13

1.75

0.08

1.76

0.17

3.70

0.74

$-0.50$

0.08

0.91

0.17 receive activities and assignments.

d. Model collaborative knowledge construction by engaging in learning with students, colleagues, and others in face-to-face and virtual environments.

$\begin{aligned} & \text { 17. Use the educational software for the course to } \\ & \text { treat academic difficulties for students or faculty }\end{aligned}$
members and their assistants.
$\begin{aligned} & \text { 18. Communicate effectively with students using } \\ & \text { communication applications to support the }\end{aligned}$
educational aspects of the course.




\begin{tabular}{|c|c|c|c|c|c|c|}
\hline $\begin{array}{l}\text { Standard / Field/ Efficiency } \\
\text { Items }\end{array}$ & $\begin{array}{c}\text { Mean } \\
\text { Statistic }\end{array}$ & $\begin{array}{c}\text { SD } \\
\text { Statistic }\end{array}$ & $\begin{array}{l}\text { Skewness } \\
\text { Statistic }\end{array}$ & SE & $\begin{array}{l}\text { Kurtosis } \\
\text { Statistic }\end{array}$ & SE \\
\hline $\begin{array}{l}\text { 19. Gives suggested solutions to problems that may } \\
\text { face the use of e-learning applications for the course. }\end{array}$ & 3.70 & 0.74 & -0.50 & 0.08 & 0.91 & 0.17 \\
\hline \multicolumn{7}{|c|}{$\begin{array}{l}\text { 2. Design and develop digital age learning experiences and assessments Teachers design, develop, and evaluate authentic learning } \\
\text { experiences and assessments incorporating contemporary tools and resources to maximize content learning in context and to develop the } \\
\text { knowledge, skills, and attitudes identified in the Standards. }\end{array}$} \\
\hline \multicolumn{7}{|c|}{ a. Design or adapt relevant learning experiences that incorporate digital tools and resources to promote student learning and creativity } \\
\hline $\begin{array}{l}\text { 20. It prepares group projects among students to } \\
\text { prepare educational content in the fields of } \\
\text { knowledge and application of the course. }\end{array}$ & 3.20 & 0.84 & -0.09 & 0.08 & 0.25 & 0.17 \\
\hline $\begin{array}{l}\text { 21. Design collaborative learning activities among } \\
\text { students for research and development of electronic } \\
\text { educational content based on global experiences. }\end{array}$ & 1.59 & 1.13 & 1.75 & 0.08 & 1.76 & 0.17 \\
\hline $\begin{array}{l}\text { 22. The information network is used to search for } \\
\text { modern topics for the curriculum in international } \\
\text { universities. }\end{array}$ & 3.14 & 1.51 & -0.39 & 0.08 & -1.39 & 0.17 \\
\hline \multicolumn{7}{|c|}{$\begin{array}{l}\text { b. Develop technology-enriched learning environments that enable all students to pursue their individual curiosities and become active } \\
\text { participants in setting their own educational goals, managing their own learning, and assessing their own progress }\end{array}$} \\
\hline $\begin{array}{l}\text { 23. Knowledge and application content is prepared } \\
\text { according to the course objectives using e-learning } \\
\text { management systems. }\end{array}$ & 2.28 & 1.05 & 1.32 & 0.08 & 1.18 & 0.17 \\
\hline $\begin{array}{l}\text { 24. Evaluates the level of student interaction with } \\
\text { learning resources through learning management } \\
\text { systems. }\end{array}$ & 1.63 & 1.21 & 1.67 & 0.08 & 1.31 & 0.17 \\
\hline $\begin{array}{l}\text { 25. It guides students to the appropriate choice of } \\
\text { digital educational resources that help achieve their } \\
\text { goals and develop their level. }\end{array}$ & 1.70 & 1.29 & 1.50 & 0.08 & 0.64 & 0.17 \\
\hline $\begin{array}{l}\text { 26. It provides feedback to students according to } \\
\text { their educational level to achieve the targeted } \\
\text { learning outcomes using digital tools. }\end{array}$ & 2.43 & 0.93 & 1.76 & 0.08 & 1.90 & 0.17 \\
\hline $\begin{array}{l}\text { 27. It is used creatively for content management } \\
\text { systems and e-learning to enable students to self- } \\
\text { assess. }\end{array}$ & 1.83 & 1.12 & 1.35 & 0.08 & 0.90 & 0.17 \\
\hline 28. Design electronic cognitive tests. & 1.59 & 1.13 & 1.75 & 0.08 & 1.76 & 0.17 \\
\hline \multicolumn{7}{|c|}{$\begin{array}{l}\text { c. Customize and personalize learning activities to address students' diverse learning styles, working strategies, and abilities using digita } \\
\text { tools and resources }\end{array}$} \\
\hline $\begin{array}{l}\text { 29. Classify the educational groups according to the } \\
\text { learning style, capabilities and technical level. }\end{array}$ & 1.59 & 1.16 & 1.73 & 0.08 & 1.61 & 0.17 \\
\hline $\begin{array}{l}\text { 30. Groups participate in planning educational } \\
\text { lessons and selecting digital resources for } \\
\text { educational content. }\end{array}$ & 1.57 & 1.13 & 1.80 & 0.08 & 1.89 & 0.17 \\
\hline $\begin{array}{l}\text { 31. Plan multi-level individual and group learning } \\
\text { activities using e-learning management systems. }\end{array}$ & 1.59 & 1.13 & 1.75 & 0.08 & 1.76 & 0.17 \\
\hline \multicolumn{7}{|c|}{$\begin{array}{l}\text { d. Provide students with multiple and varied formative and summative assessments aligned with content and technology standards, and use } \\
\text { resulting data to inform learning and teaching }\end{array}$} \\
\hline $\begin{array}{l}\text { 32. Discusses the results of individual and group } \\
\text { electronic tests with students. }\end{array}$ & 2.34 & 0.87 & 1.91 & 0.08 & 2.83 & 0.17 \\
\hline $\begin{array}{l}\text { 33. Design electronic questionnaires to measure } \\
\text { student opinion on digital content, electronic } \\
\text { teaching methods and methods, and course tests. }\end{array}$ & 2.70 & 0.85 & 0.81 & 0.08 & 1.04 & 0.17 \\
\hline $\begin{array}{l}\text { 34. Statistical analysis software is used to analyse } \\
\text { the results of opinion polls. }\end{array}$ & 2.04 & 1.11 & 1.33 & 0.08 & 1.21 & 0.17 \\
\hline $\begin{array}{l}\text { 35. It uses the results of student feedback to develop } \\
\text { the digital content of the course provided through } \\
\text { computer and e-learning. }\end{array}$ & 2.06 & 1.08 & 1.26 & 0.08 & 1.06 & 0.17 \\
\hline $\begin{array}{l}\text { 36. It relies on electronic sources to conduct } \\
\text { scientific research related to the course and } \\
\text { determine its reference sources. }\end{array}$ & 1.59 & 1.13 & 1.75 & 0.08 & 1.76 & 0.17 \\
\hline \multicolumn{7}{|c|}{$\begin{array}{l}\text { 3. Model digital age work and learning Teachers exhibit knowledge, skills, and work processes representative of an innovative professiona } \\
\text { in a global and digital society. }\end{array}$} \\
\hline
\end{tabular}




\begin{tabular}{|c|c|c|c|c|c|c|}
\hline $\begin{array}{l}\text { Standard / Field/ Efficiency } \\
\text { Items }\end{array}$ & $\begin{array}{l}\text { Mean } \\
\text { Statistic }\end{array}$ & $\begin{array}{c}\text { SD } \\
\text { Statistic }\end{array}$ & $\begin{array}{l}\text { Skewness } \\
\text { Statistic }\end{array}$ & SE & $\begin{array}{l}\text { Kurtosis } \\
\text { Statistic }\end{array}$ & SE \\
\hline $\begin{array}{l}\text { 37. Students participate in the selection and } \\
\text { employment of digital applications that contribute to } \\
\text { the cognitive and application learning of the course. }\end{array}$ & 2.70 & 0.85 & 0.81 & 0.08 & 1.04 & 0.17 \\
\hline $\begin{array}{l}\text { 38. It trains students to use e-learning tools in } \\
\text { various applications. }\end{array}$ & 1.57 & 1.13 & 1.80 & 0.08 & 1.89 & 0.17 \\
\hline $\begin{array}{l}\text { 39. It engages students in producing digital content } \\
\text { for knowledge and applications for the course. }\end{array}$ & 1.24 & 0.43 & 1.17 & 0.08 & -0.61 & 0.17 \\
\hline $\begin{array}{l}\text { 40. It works on student participation in selecting and } \\
\text { employing electronic applications that contribute to } \\
\text { assessing the cognitive and application performance } \\
\text { of the course. }\end{array}$ & 1.25 & 0.46 & 1.56 & 0.08 & 1.42 & 0.17 \\
\hline $\begin{array}{l}\text { 41. It guides students on the most important } \\
\text { problems associated with the use of educational } \\
\text { software and electronic learning tools and ways to } \\
\text { overcome them. }\end{array}$ & 1.59 & 1.13 & 1.75 & 0.08 & 1.76 & 0.17 \\
\hline \multicolumn{7}{|c|}{$\begin{array}{l}\text { b. Collaborate with students, peers, parents, and community members using digital tools and resources to support student success and } \\
\text { innovation }\end{array}$} \\
\hline $\begin{array}{l}\text { 42. He works to share the experiences of preparing } \\
\text { the digital content for the course with the assistants } \\
\text { and members of the faculty of specialization in other } \\
\text { colleges. }\end{array}$ & 2.64 & 0.81 & 0.71 & 0.08 & 0.95 & 0.17 \\
\hline $\begin{array}{l}\text { 43. Participate in joint scientific research outside the } \\
\text { college to develop the course using modern } \\
\text { technologies. }\end{array}$ & 1.76 & 1.10 & 1.60 & 0.08 & 1.81 & 0.17 \\
\hline $\begin{array}{l}\text { 44. It technically continues effectively to exchange } \\
\text { educational experiences for teaching the course with } \\
\text { colleges specialists at the Arab and international } \\
\text { levels. }\end{array}$ & 2.70 & 0.81 & 0.51 & 0.08 & 0.91 & 0.17 \\
\hline $\begin{array}{l}\text { 45. The membership of scientific journals, } \\
\text { institutions, and international entities related to the } \\
\text { specialization is shared through official websites. }\end{array}$ & 2.64 & 0.81 & 0.71 & 0.08 & 0.95 & 0.17 \\
\hline $\begin{array}{l}\text { 46. Contributes to the development of educational } \\
\text { software and electronic content in the field of } \\
\text { specialization with educational institutions and } \\
\text { institutions locally and regionally. }\end{array}$ & 1.76 & 1.10 & 1.60 & 0.08 & 1.81 & 0.17 \\
\hline \multicolumn{7}{|c|}{ c. Communicate relevant information and ideas effectively to students, parents, and peers using a variety of digital-age media and formats. } \\
\hline $\begin{array}{l}\text { 47. Evaluates the e-learning tools for the course } \\
\text { according to what is appropriate for the material and } \\
\text { human capabilities. }\end{array}$ & 2.69 & 0.86 & 1.00 & 0.08 & 0.79 & 0.17 \\
\hline $\begin{array}{l}\text { 48. It uses the available electronic communication } \\
\text { and communication channels to communicate with } \\
\text { students and parents. }\end{array}$ & 2.06 & 1.08 & 1.26 & 0.08 & 1.06 & 0.17 \\
\hline $\begin{array}{l}\text { 49. It spreads the culture of e-learning and distance } \\
\text { education and its importance to the outside world } \\
\text { through various digital technologies. }\end{array}$ & 2.70 & 0.81 & 0.51 & 0.08 & 0.91 & 0.17 \\
\hline 50. Well used software for presentations. & 4.20 & 0.79 & -0.99 & 0.08 & 1.40 & 0.17 \\
\hline 51. It uses digital sources of information related to & 2.70 & 0.81 & 0.51 & 0.08 & 0.91 & 0.17 \\
\hline
\end{tabular}

d. Model and facilitate effective use of current and emerging digital tools to locate, analyse, evaluate, and use information resources to support research and learning.

52. Controls the Windows operating system and auxiliary operations such as: creating, copying, moving, compressing and decoding files, downloading and importing them from the network.

53. The computer, tools and digital devices connected to it are used efficiently and the Internet

4.03

0.99

$-0.47$

0.08

$-0.79$

0.17

connection is used to carry out the practical activities of the course.

$\begin{array}{llllll}3.99 & 0.67 & -0.86 & 0.08 & 2.65 & 0.17\end{array}$




\begin{tabular}{|c|c|c|c|c|c|c|}
\hline $\begin{array}{l}\text { Standard / Field/ Efficiency } \\
\text { Items }\end{array}$ & $\begin{array}{l}\text { Mean } \\
\text { Statistic }\end{array}$ & $\begin{array}{c}\text { SD } \\
\text { Statistic }\end{array}$ & $\begin{array}{l}\text { Skewness } \\
\text { Statistic }\end{array}$ & SE & $\begin{array}{l}\text { Kurtosis } \\
\text { Statistic }\end{array}$ & SE \\
\hline $\begin{array}{l}\text { 54. Searches for digital resources that facilitate } \\
\text { continuous learning and distance learning } \\
\text { applications. }\end{array}$ & 3.07 & 0.79 & 0.86 & 0.08 & 1.19 & 0.17 \\
\hline $\begin{array}{l}\text { 55. He can create pages, educational blogs, email } \\
\text { and access to global libraries and databases. }\end{array}$ & 3.26 & 0.72 & 0.62 & 0.08 & 2.03 & 0.17 \\
\hline $\begin{array}{l}\text { 56. Uses office electronic applications (word } \\
\text { processing, images, graphics, and electronic tables). }\end{array}$ & 2.70 & 0.81 & 0.51 & 0.08 & 0.91 & 0.17 \\
\hline $\begin{array}{l}\text { 57. A graphical application is used to prepare } \\
\text { educational pictures for teaching the course. }\end{array}$ & 4.03 & 0.99 & -0.47 & 0.08 & -0.79 & 0.17 \\
\hline $\begin{array}{l}\text { 58. A digital video application is used to prepare } \\
\text { educational films for teaching the course. }\end{array}$ & 1.85 & 1.25 & 1.35 & 0.08 & 0.59 & 0.17 \\
\hline $\begin{array}{l}\text { 59. Produces educational materials appropriate to } \\
\text { the content of the course electronically. }\end{array}$ & 2.74 & 0.92 & 0.97 & 0.08 & 0.48 & 0.17 \\
\hline 60. Use Digital Multimedia appropriately. & 3.67 & 0.72 & -0.77 & 0.08 & 1.63 & 0.17 \\
\hline 61. Efficiently uses electronic test applications. & 3.26 & 0.72 & 0.62 & 0.08 & 2.03 & 0.17 \\
\hline $\begin{array}{l}\text { 62. It uses the means of communication and } \\
\text { electronic communication to present the results of } \\
\text { the course to students and parents. }\end{array}$ & 2.70 & 0.81 & 0.51 & 0.08 & 0.91 & 0.17 \\
\hline $\begin{array}{l}\text { 63. The International Information Network and } \\
\text { search engines are used to obtain knowledge and } \\
\text { information about the course. }\end{array}$ & 3.41 & 1.02 & -0.27 & 0.08 & -0.83 & 0.17 \\
\hline $\begin{array}{l}\text { 64. Provides sufficient information for students on } \\
\text { trusted educational websites to guide self-learning. }\end{array}$ & 3.19 & 0.71 & 0.86 & 0.08 & 2.75 & 0.17 \\
\hline $\begin{array}{l}\text { 65. It uses the basic and educational services of the } \\
\text { Internet, such as search service, e-mail, chat, file } \\
\text { transfer, and mailing lists. }\end{array}$ & 3.67 & 0.72 & -0.77 & 0.08 & 1.63 & 0.17 \\
\hline \multicolumn{7}{|c|}{$\begin{array}{l}\text { 4. Promote and model digital citizenship and responsibility Teachers understand local and global societal issues and responsibilities in an } \\
\text { evolving digital culture and exhibit legal and ethical behaviour in their professional practices. }\end{array}$} \\
\hline \multicolumn{7}{|c|}{$\begin{array}{l}\text { a. Advocate, model, and teach safe, legal, and ethical use of digital information and technology, including respect for copyright, intellectual } \\
\text { property, and the appropriate documentation of sources }\end{array}$} \\
\hline $\begin{array}{l}\text { 66. Documenting digital information sources and } \\
\text { official sites in the field of specialization with the } \\
\text { participation of students. }\end{array}$ & 1.57 & 1.15 & 1.84 & 0.08 & 2.05 & 0.17 \\
\hline $\begin{array}{l}\text { 67. Provides feedback on reliable electronic } \\
\text { applications, methods of protection and safe use of } \\
\text { them. }\end{array}$ & 1.65 & 1.20 & 1.66 & 0.08 & 1.35 & 0.17 \\
\hline $\begin{array}{l}\text { 68. It propagates a culture of intellectual property } \\
\text { rights for digital content and levels among students, } \\
\text { faculty, and assistants. }\end{array}$ & 2.70 & 0.90 & 0.97 & 0.08 & 0.53 & 0.17 \\
\hline $\begin{array}{l}\text { 69. It uses educational resources and licensed } \\
\text { electronic applications to prepare educational } \\
\text { content and encourages students to preserve } \\
\text { intellectual property rights. }\end{array}$ & 2.71 & 0.89 & 0.96 & 0.08 & 0.64 & 0.17 \\
\hline $\begin{array}{l}\text { 70. It uses licensed digital protection systems for the } \\
\text { computer operating system and smartphone. }\end{array}$ & 2.74 & 0.88 & 0.85 & 0.08 & 0.79 & 0.17 \\
\hline \multicolumn{7}{|c|}{$\begin{array}{l}\text { b. Address the diverse needs of all learners busing learner-centred strategies providing equitable access to appropriate digital tools and } \\
\text { resources }\end{array}$} \\
\hline $\begin{array}{l}\text { 71. It outlines the approved, licensed and available } \\
\text { educational technologies to meet educational needs } \\
\text { in the course. }\end{array}$ & 2.70 & 0.90 & 0.97 & 0.08 & 0.53 & 0.17 \\
\hline $\begin{array}{l}\text { 72. Provides support and guidance to enable all } \\
\text { students to use fairly digital technologies and } \\
\text { educational applications. }\end{array}$ & 3.01 & 0.78 & 0.68 & 0.08 & 1.39 & 0.17 \\
\hline $\begin{array}{l}\text { 73. It uses communication and communication } \\
\text { applications to identify obstacles to the correct use } \\
\text { of educational technologies and provide solutions to } \\
\text { them. }\end{array}$ & 2.74 & 0.87 & 0.95 & 0.08 & 0.70 & 0.17 \\
\hline \multicolumn{7}{|l|}{ c. Promote and model digital etiquette and responsib } \\
\hline $\begin{array}{l}\text { 74. Identifies electronic applications appropriate to } \\
\text { the nature of the course's teaching. }\end{array}$ & 2.61 & 0.97 & 1.30 & 0.08 & 0.66 & 0.17 \\
\hline
\end{tabular}




\begin{tabular}{|c|c|c|c|c|c|c|}
\hline $\begin{array}{l}\text { Standard / Field/ Efficiency } \\
\text { Items }\end{array}$ & $\begin{array}{l}\text { Mean } \\
\text { Statistic }\end{array}$ & $\begin{array}{c}\text { SD } \\
\text { Statistic }\end{array}$ & $\begin{array}{l}\text { Skewness } \\
\text { Statistic }\end{array}$ & SE & $\begin{array}{l}\text { Kurtosis } \\
\text { Statistic }\end{array}$ & SE \\
\hline $\begin{array}{l}\text { 75. Specifies guidelines for the optimal use, of } \\
\text { course, digital resources through learning } \\
\text { management systems and the Internet. }\end{array}$ & 2.33 & 1.13 & 0.57 & 0.08 & -0.29 & 0.17 \\
\hline $\begin{array}{l}\text { 76. It outlines procedures agreed with students for } \\
\text { the optimal use of social media applications in } \\
\text { course learning. }\end{array}$ & 2.74 & 0.87 & 0.95 & 0.08 & 0.70 & 0.17 \\
\hline \multicolumn{7}{|c|}{$\begin{array}{l}\text { d. Develop and model cultural understanding and global awareness by engaging with colleagues and students of other cultures using digital } \\
\text { age communication and collaboration tools }\end{array}$} \\
\hline $\begin{array}{l}\text { 77. Plan collaborative research activities based on } \\
\text { digital resources and technical communication in the } \\
\text { curriculum at the local and international levels. }\end{array}$ & 1.41 & 0.49 & 0.35 & 0.08 & -1.87 & 0.17 \\
\hline $\begin{array}{l}\text { 78. Students engage with collaborators, faculty, and } \\
\text { experts in research studies in the field of } \\
\text { specialization. }\end{array}$ & 2.20 & 0.95 & 1.31 & 0.08 & 1.59 & 0.17 \\
\hline \multicolumn{7}{|c|}{$\begin{array}{l}\text { 5. Engage in professional growth and leadership Teachers continuously improve their professional practice, model lifelong learning, and } \\
\text { exhibit leadership in their school and professional community by promoting and demonstrating the effective use of digital tools and resources. }\end{array}$} \\
\hline \multicolumn{7}{|c|}{ a. Participate in local and global learning communities to explore creative applications of technology to improve student learning. } \\
\hline $\begin{array}{l}\text { 79. It provides educational applications and digital } \\
\text { content for specialization as part of projects to attract } \\
\text { scholars from abroad. }\end{array}$ & 1.54 & 1.07 & 1.89 & 0.08 & 2.36 & 0.17 \\
\hline $\begin{array}{l}\text { 80. He uses modern digital technologies to provide } \\
\text { educational services and contents for the course } \\
\text { remotely. }\end{array}$ & 3.64 & 0.72 & -1.23 & 0.08 & 2.75 & 0.17 \\
\hline $\begin{array}{l}\text { 81. Establish virtual classrooms on educational } \\
\text { platforms to spread specialization and exchange } \\
\text { ideas, methods, information and knowledge. }\end{array}$ & 2.61 & 0.97 & 1.30 & 0.08 & 0.66 & 0.17 \\
\hline $\begin{array}{l}\text { 82. Participates in the development of solutions for } \\
\text { the difficulties of learning the course using technical } \\
\text { education software. }\end{array}$ & 1.59 & 1.14 & 1.75 & 0.08 & 1.73 & 0.17 \\
\hline \multicolumn{7}{|c|}{$\begin{array}{l}\text { b. Exhibit leadership by demonstrating a vision of technology infusion, participating in shared decision making and community building, and } \\
\text { developing the leadership and technology skills of others. }\end{array}$} \\
\hline $\begin{array}{l}\text { 83. Contributes to the preparation of electronic } \\
\text { meetings held remotely to benefit from experiences } \\
\text { and develop a specialization. }\end{array}$ & 1.65 & 1.27 & 1.68 & 0.08 & 1.27 & 0.17 \\
\hline $\begin{array}{l}\text { 84. Participates in formulating e-learning recruitment } \\
\text { experiences for the course in preparation for } \\
\text { preparing a comprehensive vision to benefit from } \\
\text { technology. }\end{array}$ & 1.57 & 1.15 & 1.84 & 0.08 & 2.05 & 0.17 \\
\hline $\begin{array}{l}\text { 85. Participates in technical training programs to } \\
\text { acquire and develop personal technical skills and } \\
\text { help others to acquire them. }\end{array}$ & 3.01 & 0.77 & 0.17 & 0.08 & 2.29 & 0.17 \\
\hline \multicolumn{7}{|c|}{$\begin{array}{l}\text { c. Evaluate and reflect on current research and professional practice on a regular basis to make effective use of existing and emerging digital } \\
\text { tools and resources in support of student learning. }\end{array}$} \\
\hline $\begin{array}{l}\text { 86. It uses educational digital resources, e-learning } \\
\text { applications, tests and opinion polls in the course. }\end{array}$ & 1.60 & 1.22 & 1.79 & 0.08 & 1.76 & 0.17 \\
\hline $\begin{array}{l}\text { 87. Participates in official events at the university, } \\
\text { college, community, schools, and parents to raise } \\
\text { awareness of the effective use of digital resources. }\end{array}$ & 2.61 & 0.97 & 1.30 & 0.08 & 0.66 & 0.17 \\
\hline \multicolumn{7}{|c|}{ d. Contribute to the effectiveness, vitality, and self-renewal of the teaching profession and of their school and community } \\
\hline $\begin{array}{l}\text { 88. It applies the technical and educational } \\
\text { specifications of the e-learning programs to the } \\
\text { course. }\end{array}$ & 1.58 & 1.17 & 1.76 & 0.08 & 1.64 & 0.17 \\
\hline $\begin{array}{l}\text { 89. Evaluate the educational software prepared for } \\
\text { the curriculum in terms of education and learning. }\end{array}$ & 2.39 & 0.89 & 1.87 & 0.08 & 2.45 & 0.17 \\
\hline $\begin{array}{l}\text { 90. Actively contributes to outreach activities on the } \\
\text { use of digital resources. }\end{array}$ & 2.32 & 0.95 & 1.39 & 0.08 & 1.61 & 0.17 \\
\hline
\end{tabular}

